\title{
THE EFFECT OF MAHKOTA DEWA (PHALERIA MACROCARPA) (SCHEFF.) FRUIT PERICARP EXTRACT ON INOS IN MICE COLON INTERMITTENTLY-INDUCED BY DEXTRAN SODIUM SULFATE
}

\author{
K KUSMARDI ${ }^{1}$, A ESTUNINGTYAS ${ }^{2}$, D SHAVERA ${ }^{4,5 *}$, A TEDJO ${ }^{3}$, BP PRIOSOERYANTO ${ }^{6}$ \\ ${ }^{1}$ Department of Anatomic Pathology, ${ }^{2}$ Department of Pharmacology, ${ }^{3}$ Department of Chemistry, ${ }^{4}$ Master Program in Biomedical Sciences, \\ Faculty of Medicine, Universitas Indonesia, Jakarta, Indonesia, ${ }^{5}$ National Agency of Drug and Food Control, Republic of Indonesia, ${ }^{6}$ Divison \\ of Veterinary Pathology Faculty Veterinary Medicine, Bogor Agricultural University(IPB), Bogor, Indonesia. \\ Email: shaveradilla@gmail.com
}

Received: 23 July 2017, Revised and Accepted: 09 September 2017

\section{ABSTRACT}

Objective: The objective of this research was to investigate the anti-inflammatory effect of Mahkota Dewa fruit pericarp extract (Phaleria macrocarpa) on inducible nitric oxide synthase (iNOS) in mice colon induced by dextran sodium sulfate (DSS).

Method: The simplisia of P. macrocarpa pericarp was weighed $(1000 \mathrm{~g})$ and extracted by maceration process. The total yield of the ethanolic extract was $26.43 \%$. Phytochemical screening was carried out for the detection of the phytoconstituents by simple qualitative methods. The antiinflammatory activity was performed by DSS-induced colitis model through assessment of hematoxylin-eosin staining and expression of iNOS by immunohistochemistry assay at four different doses, i.e., 650, 1250, 2500, and $5000 \mathrm{mg} / \mathrm{kg}$. Swiss Webster male mice weighing 25-30 g were used for the study.

Results: Inflammation score in dose 625,1250,2500, and $5000 \mathrm{mg} / \mathrm{kg}$ were $1.63,1.43,1.32$, and 2.20, respectively. This result is significantly different $(\mathrm{p}=0.008)$ with DSS group that was 4.37. The results of iNOS optical density score in dose $625,1250,2500$, and $5000 \mathrm{mg} / \mathrm{kg}$ were $1.21,1.119,1.22$, and 1.37, respectively. This result was significantly different $(\mathrm{p}=0.000)$ with DSS group that was 2.24 .

Conclusion: Pericarp extract of $P$. macrocarpa fruit exhibited anti-inflammatory activity in the experimental model shown by suppressing the expression of inflammatory cell and iNOS.

Keywords: Pericarp, Phaleria macrocarpa, Inflammatory cells, Inducible nitric oxide synthase, Dextran sodium sulfate, Colon.

(c) 2017 The Authors. Published by Innovare Academic Sciences Pvt Ltd. This is an open access article under the CC BY license (http://creativecommons. org/licenses/by/4. 0/) DOI: http://dx.doi.org/10.22159/ajpcr.2017.v10i12.21560

\section{INTRODUCTION}

The risk of colorectal cancer in ulcerative colitis patients was increase with time of exposure to the disease, i.e., $1.6 \%$ after 10 years, $8.3 \%$ after 20 years, and $18.4 \%$ after 30 years [1]. The etiology of ulcerative colitis is not yet known, but there were several factors that play a role in the development of the disease, among others, genetic disorders that cause T-cell responses become aggressive and excessive to subset of commensal enteric bacteria, environmental factors that can damage the mucosal barium rapidly and stimulate immune response, and enteric bacterial equilibrium disorders. Excessive immune responses to the colon will cause impairment of epithelial function and epithelial response to pathogens [2-4]. Besides, oxidative stress also associated with ulcerative colitis as revealed by Geetha et al. [5]

The current anti-inflammatory therapy aims to control the cardinal signs of inflammation, antagonizing or blocking key proinflammatory mediators that are released at the beginning of an acute inflammatory response. However, prolonged use of many anti-inflammatory agents has serious adverse reactions such as gastric intolerance and bone marrow depression [6]. Hence, it is important to search for substances that can promote resolution of inflammation, homeostatic, and modulators efficient and which are tolerated by the body [7]

The development of standardized herbal medicines with proven efficacy and safety can be considered as an important source for increasing the access of people toward medicine and offers new therapeutic options [8]. Phaleria macrocarpa known as Mahkota Dewa is a traditional medicinal plant in Indonesia. Literature indicates in vitro anti-inflammatory activity of $P$. macrocarpa fruit pericarp extract [9]. In vivo study conducted by Tjandrawinata et al. showed anti-inflammatory activities of bioactive fraction obtained from a combination of P. macrocarpa and Nigella sativa [10].

Flavonoid content of $P$. macrocarpa has proven to decrease expression of inducible nitric oxide synthase (iNOS), an enzyme that plays a role in the synthesis of NO which then can influence the production of proinflammatory cytokines and cause the reactive oxygen state and then will cause mucosal damage [11].

Since in vivo anti-inflammatory activity of single $P$. macrocarpa fruit pericarp extract has never been published, meanwhile in vitro activity has been proven, we undertaken this researched to investigate in vivo anti-inflammatory activity of $P$. macrocarpa fruit pericarp extract.

\section{METHODS}

Materials

All the solvents and chemicals required were of analytical grade. Dextran sodium sulfate was obtained from Regent Science Industry Ltd (RSC), Hong Kong, iNOS antibody was obtained from Abcam Inc., Cambridge, MA, Aspirin was obtained from a local drug store, Jakarta.

Experimental animals

Healthy male Swiss Webster mice about (25-30 g) were procured from Veterinary Laboratory of Research and Development Centre, Ministry of Health, Jakarta. The animals were maintained under standard conditions of relative humidity and temperature and acclimatized under 
laboratory conditions before carrying out the experiments. Ethical approval was obtained from The Health Research Ethics Committee, Faculty of Medicine Universities Indonesia, number 24/UN2. FI/ ETIK/1/2017

\section{Phytochemical screening}

Phytochemical screening was carried out for the detection of alkaloids, flavonoids, tannin, saponin, quinoa, and steroid by simple qualitative methods [12].

\section{Colitis induction and tissue preparation}

Dextran sodium sulfate $2 \%$ is given through drinking water for 7 days and then punctuated with 7 days without administration of DSS. This cycle is then repeated up to 3 cycles. The dosage of the test drug was designed based on previous publication research [13,14]. 42 experimental animals were divided into seven groups with six animals in each group. Mice were sacrificed at the end of week 7 by dislocation of the neck, subsequently, colon tissue put into $10 \%$ formalin buffer solution. Then paraffin blocks are made and afterward hematoxylineosin and immunohistochemical staining was then performed in accordance with standard laboratory procedures (Fig. 1).

Fig. 1: Research flow. ASP $=$ Aspirin, EPMD $1=$ Phaleria macrocarpa pericarp extract doses $625 \mathrm{mg} / \mathrm{kg}$, EPMD II = P. macrocarpa pericarp extract doses $1250 \mathrm{mg} / \mathrm{kg}$, EPMD III $=$ P. macrocarpa pericarp extract doses $2500 \mathrm{mg} / \mathrm{kg}$, and EPMD $1 \mathrm{~V}=$ P. macrocarpa pericarp extract doses $5000 \mathrm{mg} / \mathrm{kg}$

\section{Hematoxylin eosin staining}

The procedures for hematoxylin-eosin staining were in accordance with previous studies [15], in brief, deparaffinized section using xylol then re-hydrated using alcohol and washed in running water. The preparation inserted into hematoxylin (Meyer solution), rinsed in running water and dipped into a saturated lithium carbonate, after that rinsed with running water for 5 minutes.

\section{Histopathology assessment result}

Analysis of histopathological changes made by reading the outward appearance in a blind way, and performed by two technicians, then the results were averaged. Readings were taken at 400 times magnification. Preparations were taken every five representative fields of view, then assessed the score of severity, extent and level of inflammation [16].

\section{iNOS immunohistochemical staining}

After deparaffinization and rehydration, specimens were soaked by $3 \%$ of hydrogen peroxide to eliminate endogenous peroxide and then with $0.01 \mathrm{M}$ of citrate buffer ( $\mathrm{pH} \mathrm{6.0)}$ in microwave to return the structure of the antigen and then spilled with $5 \%$ normal serum to block unspecific protein. The next step was incubated the specimens with rabbit

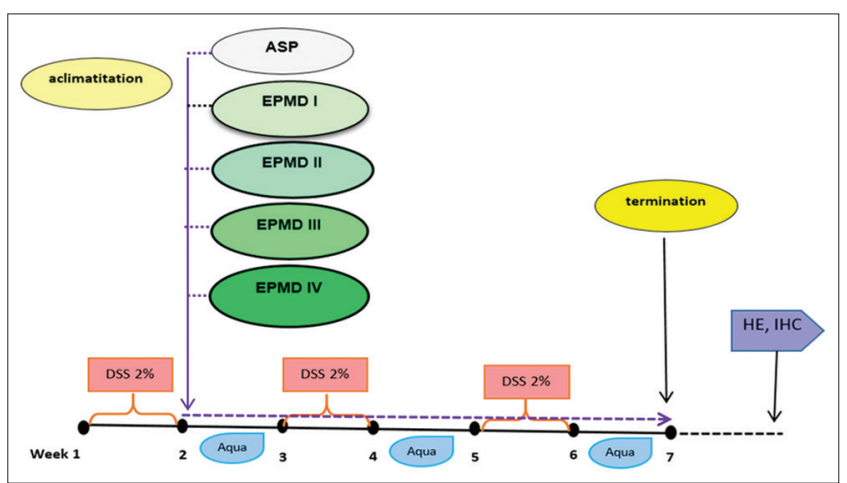

Fig. 1: Research flow. ASP = Aspirin,

EPMD 1 = Phaleria macrocarpa pericarp extract doses $625 \mathrm{mg} / \mathrm{kg}$, EPMD II = P. macrocarpa pericarp extract doses $1250 \mathrm{mg} / \mathrm{kg}$

EPMD III = P. macrocarpa pericarp extract doses $2500 \mathrm{mg} / \mathrm{kg}$, and EPMD 1V = P. macrocarpa pericarp extract doses $5000 \mathrm{mg} / \mathrm{kg}$ polyclonal antibodies of inducible nitric oxide synthase (1:100 dilution) followed by appropriate secondary antibody, HRP-conjugated streptavidin and 3,3'-diaminobenzidine (DAB) subsequently. Next counterstained with Harris hematoxylin, dehydrated and mounting.

Reading was taken at 400 times magnification and every five representative fields of view. The interpretation of results was using image J profiler software that will assess the percentage of color intensity as high positive, positive, low positive, and negative, and then optical density score calculated $[17,18]$ using the formula:

$\underline{\left\{\begin{array}{l}(\% \text { high positive } \times 4)+(\% \text { positive } \times 3)+(\% \text { low positive } \times 2) \\ +(\% \text { negative } \times 1)\end{array}\right\}}$

100

\section{Statistical analysis}

The values were expressed as mean standard deviation. $\mathrm{P}<0.05$ was considered significant, denoted by symbol $(*)$. The data were analyzed by one-way analysis of variance followed by Tukey multiple comparisons using SPSS 20 Software. Inhomogeneous data analyzed non-parametrically by Kruskal-Wallis.

\section{RESULTS}

\section{Phytochemical screening}

The phytochemical screening of ethanolic extract of $P$. macrocarpa pericarp showed the presence of flavonoids and saponin.

\section{Histopathological outcome}

All doses of $P$. macrocarpa pericarp extractable to reduce infiltration inflammation significantly different from the DSS group $(\mathrm{p}=0.008)$ (Figs. 2 and 3).

Fig. 2: Graph score of mice colon tissue inflammation. All values are shown as mean \pm standard of error and $n=6 .{ }^{*} \mathrm{p}<0.05$ compared to the DSS group. DSS = Dextran sodium sulfate, ASP = Aspirin, $\mathrm{EPMD}=$ Phaleria macrocarpa pericarp extract

Fig. 3: An overview of histopathological results of colon tissue of mice, (a) Healthy tissue from normal mice, (b) inflammatory tissue of DSS group, (c) inflammatory tissue of aspirin group, (d-g) inflammatory tissue of Phaleria macrocarpa pericarp extract group dose 652,1250, 2500, and $5000 \mathrm{mg} / \mathrm{kg}$, yellow arrow shows inflammation in epithelial cell crypt, HE 400x, iNOS expression after immunohistochemical readings

Normal group showed weak expression of iNOS in the cytoplasmic of epithelial cell crypt, in contrast to the strong expression in DSS group. While iNOS expression in P. macrocarpa extract doses 625 and

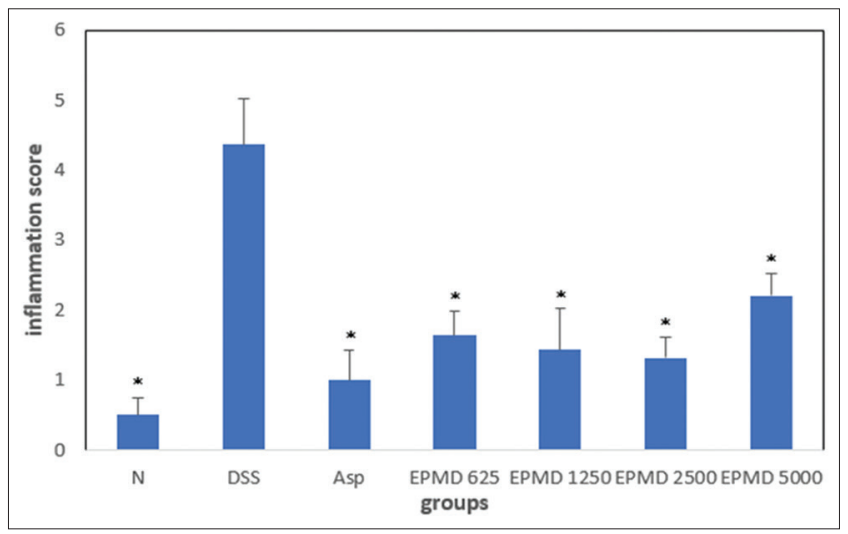

Fig. 2: Graph score of mice colon tissue inflammation. All values are shown as mean \pm standard of error and $n=6$. ${ }^{*} p<0.05$ compared to the DSS group. DSS = Dextran sodium sulfate, ASP = Aspirin, EPMD = Phaleria macrocarpa pericarp extract 
$1250 \mathrm{mg} / \mathrm{kg}$ weaker than doses 2500 and $5000 \mathrm{mg} / \mathrm{kg}$ (Fig. 4).

Fig. 4: INOS expression on the mice colon tissue. (a) Healthy tissue from normal mice, (b) iNOS expression of DSS group, (c) aspirin group, (d-g) iNOS expression of Phaleria macrocarpa pericarp extract group dose $652,1250,2500$, and $5000 \mathrm{mg} / \mathrm{kg}$. Yellow arrow is showing iNOS expression in the cytoplasm of epithelial cell crypt $($ IHC $\times 400)$

P. macrocarpa pericarp extract can significantly decrease iNOS expression in cytoplasmic of epithelial crypt compared with DSS groups $(p=0.000)$ as shown in Fig. 5.

Fig. 5: Graph score of iNOS expression in mice colon tissue. All values are shown as mean \pm standard of error and $n=6 .{ }^{*} p<0.05$. DSS $=$ Dextran sodium sulfate group, $\mathrm{ASP}=$ Aspirin group, $\mathrm{EPMD}=$ Phaleria macrocarpa pericarp extract group, ${ }^{*} \mathrm{p}=0.001$ compared to the DSS group

\section{DISCUSSION}

All dose of $P$. macrocarpa pericarp extract can decreased inflammation; this result strengthens the evidence of anti-inflammatory activity from previous in vitro studies in which flavonoid content inhibit $63.4 \%$ NO production and classified as potentially moderate antiinflammation $[10,19]$. Flavonoid apparently working through several mechanisms includes antioxidative effect, direct free radicals scavenger, immobilization leukocyte, and interaction with enzyme system. Flavonoid of $P$. macrocarpa pericarp extract containing kaempferol and myricetin grouped as flavone which working as an antioxidant through reaction with free radicals producing more stable and less reactive compound [20].

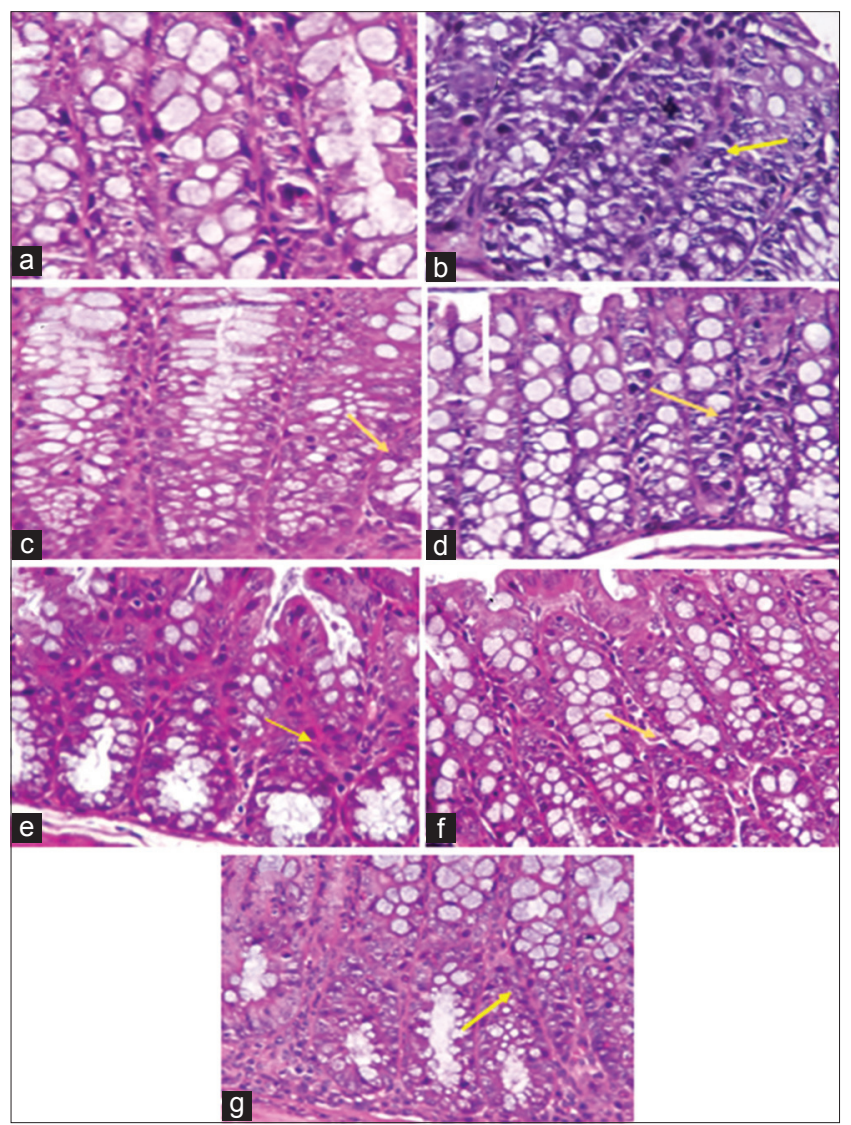

Fig. 3: An overview of histopathological results of colon tissue of mice, (a) Healthy tissue from normal mice, (b) inflammatory tissue of DSS group, (c) inflammatory tissue of aspirin group,

(d-g) inflammatory tissue of Phaleria macrocarpa pericarp extract group dose $652,1250,2500$, and $5000 \mathrm{mg} / \mathrm{kg}$, yellow arrow shows inflammation in epithelial cell crypt, HE 400×, iNOS expression after immunohistochemical readings
Flavonoids of pericarp extract such kaempferol have anti-inflammatory effects in vitro and in silico through NF- $\mathrm{BB}$ activation barrier and have the binding energy and the same docking position with inhibitors NF- $\kappa B$.

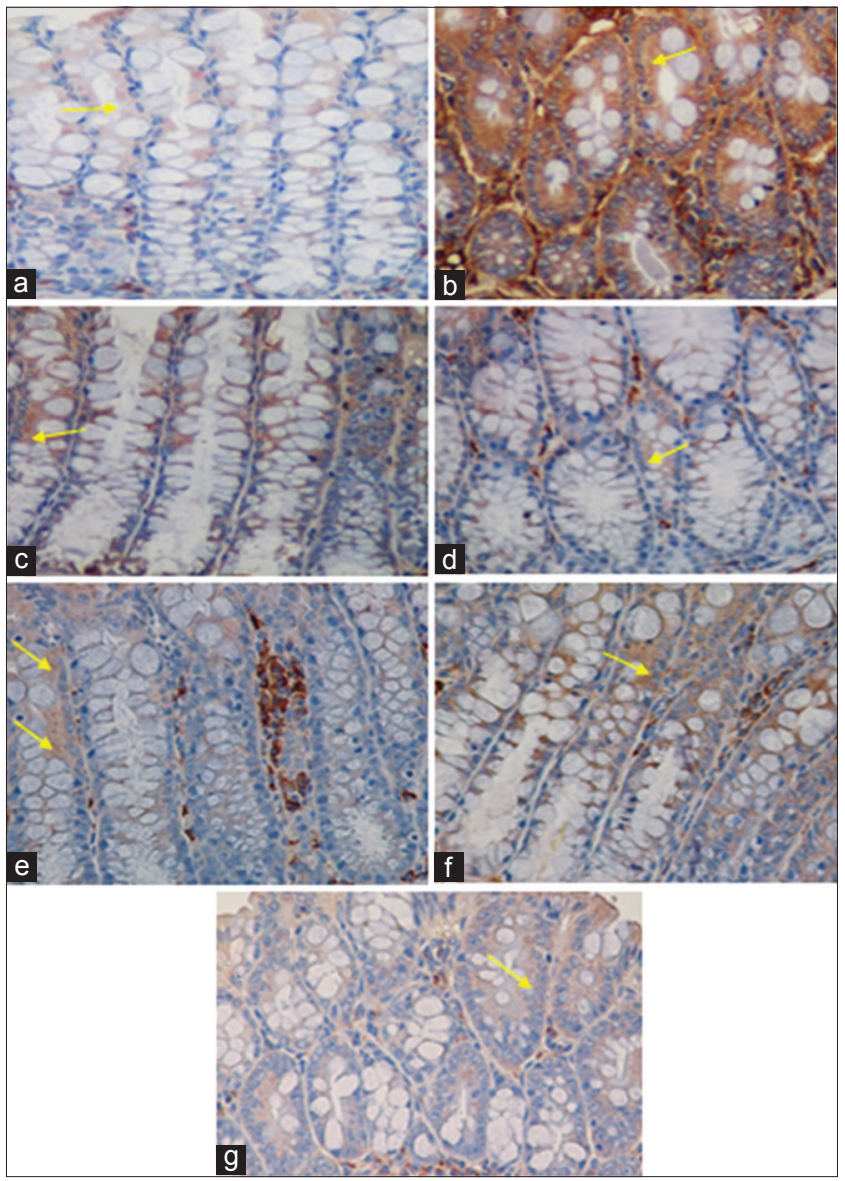

Fig. 4: INOS expression on the mice colon tissue. (a) Healthy tissue from normal mice, (b) iNOS expression of DSS group, (c) aspirin group, (d-g) iNOS expression of Phaleria macrocarpa pericarp extract group dose 652, 1250, 2500, and $5000 \mathrm{mg} / \mathrm{kg}$. Yellow arrow is showing iNOS expression in the cytoplasm of epithelial cell crypt (IHC $\times \mathbf{4 0 0})$

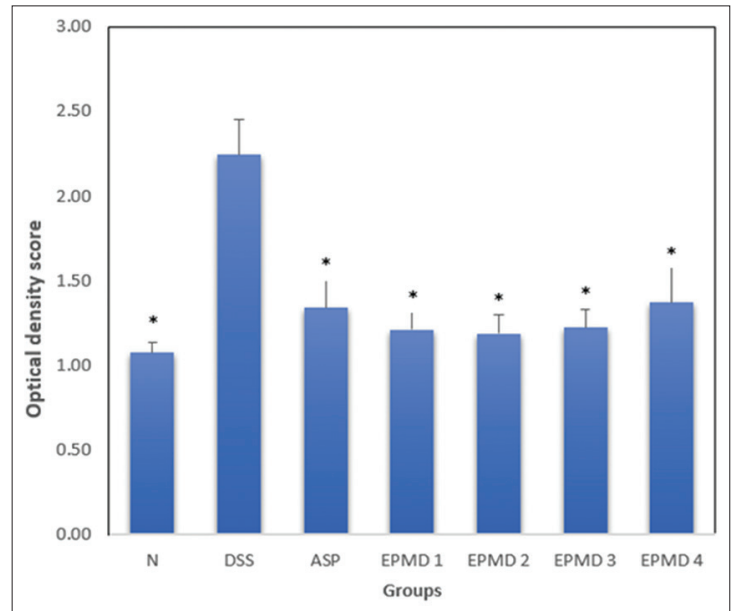

Fig. 5: Graph score of iNOS expression in mice colon tissue. All values are shown as mean \pm standard of error and $n=6 .{ }^{*} p<0.05$.

DSS $=$ Dextran sodium sulfate group, $\mathrm{ASP}=$ Aspirin group, $\mathrm{EPMD}=$ Phaleria macrocarpa pericarp extract group, ${ }^{*} \mathrm{p}=0.001$ compared to the DSS group 
$\mathrm{NF}-\kappa \mathrm{B}$ is activated by various stimuli including lipopolysaccharides from bacterial cell walls, proinflammatory cytokines, and viral DNA. This stimulus can induce intracellular signaling cascade that activates IкB kinase complex (IKK) to phosphorylate specific serine residues in the molecule I $\kappa$ B. Phosphorylation of I $\kappa$ B bonds in NF- $\kappa$ B will degrade NF- $\mathrm{B}$ I $\kappa \mathrm{B}$ so it can translocate into the nucleus [14]. Kaempferol can inhibit endothelial adhesion molecules, such as intercellular adhesion molecule-1 (ICAM-1), which upregulate during inflammation and help recruitment leukocytes, migration and activation of T cell. Kaempferol inhibits the expression of mRNA and ICAM-1 proteins resulting in blockage of leukocyte uptake and migration and T cell activation [21].

Anti-inflammatory activity of $P$. macrocarpa pericarp extract also proven through decreasing of iNOS expression in mice colon, this results in line with Rostoka et al. [22] and Choi et al. [23] whom study flavonoid isolates, state that kaempferol, myricetin and rutin lowering iNOS protein expression in the livers of mice, and myricetin lowering nitric oxide production in rat liver. Besides kaempferol, myricetin and rutin, naringin also can inhibit the activation of iNOS enzyme and activation of NF- $\kappa$ B through barriers to degrades I $\kappa$ B and translocation of $\mathrm{p} 65$, a subunit of the protein NF- $\mathrm{\kappa B}$ which undergo translocation into

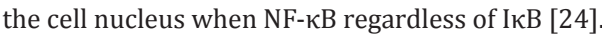

\section{CONCLUSION}

The phytochemical screening of ethanolic extract of $P$. macrocarpa pericarp showed the presence of flavonoids and saponin. All doses of $P$. macrocarpa pericarp extract can suppress inflammatory cells in epithelial crypt induced by DSS as indicated by decreasing inflammatory score compare to DSS group ( $\mathrm{p}=0.008)$. All doses of P. macrocarpa pericarp extract can decrease expression of iNOS on mice colon epithelial crypt induced by DSS compare to DSS group $(\mathrm{p}=0.000)$.

\section{ACKNOWLEDGMENTS}

We would like to thank for Directorate of Research and Public Services Universitas Indonesia, for PITTA 2017 Grand and Ministry of Research, Technology, and Higher Education for PUPT 2016 Grand.

\section{REFERENCES}

1. Zhiqin W, Palaniappan S, Raja Ali RA. Inflammatory Bowel Diseaserelated Colorectal Cancer in the Asia-Pacific Region: Past, present, and future. Intest Res 2014;12(3):194-204.

2. Waldner MJ, Neurath MF. Mechanisms of immune signaling in colitisassociated cancer. Cell Mol Gastroenterol Hepatol 2015;1:6-16.

3. Sartor RB. Mechanisms of disease: Pathogenesis of Crohn's disease and ulcerative colitis. Nat Clin Pract Gastroenterol Hepatol 2006;3(7):390-407.

4. Coskun M. Intestinal epithelium in inflammatory Bowel disease. Front Med Gastroenterol 2014;1(24):1-5.

5. Geetha P, Kumar BL, Indra U, Sheetal P. Role of antioxidant and myeloperoxidase levels in 7, 12-dimethylbenz [a] anthracene induced experimental rat model: Evidence for oxidative damage in active ulcerative colitis. Int J Pharm Pharm Sci 2017;9(3):282-6.

6. Triantafillidis JK, Merikas E, Georgopoulos F. Current and emerging drugs for the treatment of inflammatory bowel disease. Drug Des Devel
Ther 2011;5:185-210.

7. Serhan $\mathrm{CN}$, Oliw E. Unorthodox routes to prostanoid formation: New twists in cyclooxygenase-initiated pathways. J Clin Invest 2001;107(12):1481-9.

8. Balunas MJ, Kinghorn AD. Drug discovery from medicinal plants. Life Sci 2005;78(5):431-41

9. Hendra R, Ahmad S, Oskoueian E, Sukari A, Shukor MY. Antioxidant, anti-inflammatory and cytotoxicity of Phaleria macrocarpa (Boerl.) Scheff Fruit. BMC Complement Altern Med 2011;11:110.

10. Tjandrawinata RR, Djunarko I, Fenty F, Hendra P. Anti-inflammation effects of bioactive fraction dlbs0533 containing Phaleria macrocarpa and Nigella sativa on animal model. Int $\mathrm{J}$ Pharm Pharm Sci 2014;7(1):408-11.

11. Zamora R, Vodovotz Y, Billiar TR. Inducible nitric oxide synthase and inflammatory diseases. Mol Med 2000;6(5):347-73.

12. Ghori SS, Khan M, Khan SA, Baig MD. Antihyperglycaemic effect of Ficus dalhousiae Miq leaf ethanolic extract in alloxan-Induced diabetic rats. Int J Pharm Pharm Sci 2014;6(9):132-6.

13. Syukri Y, Saepudin S. Anticarcinogenesis activity of ethanol extract of the crown of the god fruits in mice induced by 7,12-dimetilbenz(a) anthracene. J Ilm Kefarm Indones. JIKF 2008;6(2):63-7.

14. Suprapti T, Louisa M, Tedjo A, Kusmardi K, Fadilah F. Antiinflammatory effect of mahkota dewa (Phaleria macrocarpa (Scheff.) (Boerl.) leaves extract on colon carcinogenesis induced by azoxymethane and dextran sodium sulphate: Focus on the iNOS, $\beta$-catenin and COX-2 Expression. Asian Aust J Anim Sci 2014;2(4):511-27.

15. Amalia AW, Kusmardi S, Elya B, Arsianti A. Inhibition of carcinogenesis by seed and soybean meal extract in colon of mice: Apoptosis and dysplasia. Asian J Pharm Clin Res 2017;10(4):123-8.

16. Roger R, Eastham-Anderson J, DeVoss J, Lesch J, Yan D. Image analysis-based approaches for Scoring mouse models of colitis. Vet Pathol 2015;53(1):1-11.

17. Jafari MS, Hunger RE. IHC optical density score: A New practical method for quantitative immunohistochemistry image analysis. Appl Immunohistochem Mol Morphol 2017;25(1):1-2

18. Varghese F, Bukhari AB, Malhotra R, De A. IHC Profiler: An open source plugin for the quantitative evaluation and automated scoring of immunohistochemistry images of human tissue samples. PLoS One 2014;9(5):1-11.

19. Hendra R, Ahmad S, Sukari A, Shukor MY, Oskoueian E. Flavonoid analyses and antimicrobial activity of various parts of Phaleria macrocarpa (Scheff.) Boerl fruit. Int J Mol Sci 2011;12(6):3422-31.

20. Nijveldt RJ, van Nood E, van Hoorn DE, Boelens PG, van Norren K, van Leeuwen PA. Flavonoids: A review of probable mechanisms of action and potential applications. Am J Clin Nutr 2001;74(4):418-25.

21. Kadioglu O, Nass J, Saeed ME, Schuler B, Efferth T. Kaempferol Is an Anti-Inflammatory Compound with Activity towards NF-?B Pathway Proteins. Anticancer Res 2015;35(5):2645-50.

22. Rostoka E, Baumane L, Isajevs S, Line A, Dzintare M, Svirina D, et al. Effects of kaempferol and myricetin on inducible nitric oxide synthase expression and nitric oxide production in rats. Basic Clin Pharmacol Toxicol 2010;106(6):461-6.

23. Choi KS, Kundu JK, Chun KS, Na HK, Surh YJ. Rutin inhibits UVB radiation-induced expression of COX-2 and iNOS in hairless mouse skin: P38 MAP kinase and JNK as potential targets. Arch Biochem Biophys 2014;559:38-45.

24. Liu Y, Wu H, Nie YC, Chen JL, Su WW, Li PB. Naringin attenuates acute lung injury in LPS-treated mice by inhibiting NF-?B pathway. Int Immunopharmacol 2011;11(10):1606-12. 